\title{
Changes in serum and urinary potassium levels during profound hypothermia in man
}

\author{
L. LANGDON AND D. P. E. KINGSLEY \\ From the Departments of Pathology and Anaesthetics, \\ St. Bartholomews Hospital, London
}

SYNOPSIS Samples of blood were taken at five to 10-minute intervals during cooling, circulatory arrest, and rewarming in eight consecutive patients undergoing open cardiac surgery under profound hypothermia at nasopharyngeal and oesophageal temperatures of approximately $10^{\circ} \mathrm{C}$. and the serum potassium levels were estimated. Urine samples were also collected from six of the eight patients and the total potassium excretion calculated per minute. It was found that there was a tendency for the serum potassium level to rise towards the end of cooling. A further more significant rise occurred during circulatory arrest, and on rewarming there was a pronounced fall of approximately $2.5 \mathrm{mEq}$./litre, the lowest level being reached at $27 \cdot 5^{\circ} \mathrm{C}$. Above $27 \cdot 5^{\circ} \mathrm{C}$. there was no further significant change in the serum potassium level. It is suggested that the acidosis which occurs during circulatory arrest and a depression in the function of the cell membrane at very low temperatures are at least partly responsible for the changes in serum potassium. Certainly the excretion of potassium in the urine does not account for them.

Changes are known to occur during hypothermia in the level of the serum potassium. Some workers have observed a fall during cooling (Munday, Blane, Chin, and Machell, 1958; Gollan, Rudolph, and Olsen, 1957; Yonce, Dykers, and McGee, 1962). Others have observed a rise in the potassium level during cooling and a fall during rewarming (Dunlop and Curnow, 1962; Sarajas, 1962). The temperatures at which changes occur are not known with any accuracy. We therefore decided to undertake serial estimations of the serum potassium levels in patients undergoing hypothermia to see what changes occur in man and if there is any relationship between the serum potassium level and the body temperature.

\section{METHOD}

Profound hypothermia was achieved by a modification of Drew's technique (Drew and Anderson, 1959; Hurt, 1962). Two De Bakey double roller pumps were used to maintain respectively the systemic and pulmonary circulations, the patients' own lungs being used for gaseous exchange. Blood from the cannulated left atrium passed into a reservoir and was pumped through a heat exchanger into the femoral artery. A separate reservoir received blood from the right atrium and this blood was pumped into the pulmonary circulation by

Received for publication 5 December 1963. means of a cannula passed through the right ventricular wall.

The patients were anaesthetized using nitrous oxide, oxygen, and fluothane. Following endotracheal intubation they were manually ventilated using the same agents in a semi-closed system with carbon dioxide absorption.

Once the oesophageal temperature had fallen to $30^{\circ} \mathrm{C}$. the patients were ventilated with $100 \%$ oxygen only. No further anaesthetic agents were administered until rewarming was complete when nitrous oxide was reintroduced into the system. Temperatures were recorded from the oesophagus and nasopharynx using an Ellab electric thermometer.

The patients were given heparin (Boots Pure Drug Co.) using a dosage of $3 \mathrm{mg} . / \mathrm{kg}$. body weight. The hypothermia unit was primed with 2 litres acid citrate dextrose blood, $60 \mathrm{mg}$. heparin and $5 \mathrm{ml} .20 \%$ calcium chloride solution being added to each litre.

Two disposable blood transfusion giving set needles, size $15 / 10$, were inserted, one into each of the venous return lines from the right and left atria. Specimens for potassium estimation were taken from the right outflow line except when only the pump on the left side was operating, usually for a few minutes at the beginning and end of perfusion. Each sample was centrifuged immediately at 3,000 r.p.m. and the serum separated to prevent possible movement of potassium ions either into or out of the red cells during equilibration at room temperature.

The potassium levels were estimated using an EEL 
flame photometer. Samples were taken pre-operatively, every five to 10 minutes during cooling, and at least every five minutes during rewarming, the first one following circulatory arrest being one minute after perfusion was begun again. Samples were also taken from both reservoirs at the beginning and end of circulatory arrest and from the heat exchanger just before rewarming.

Urine was collected with a Gibbon no. 8 polythene catheter, which was inserted into the bladder upon induction of anaesthesia. Samples were taken continuously and the total potassium excretion calculated per minute.

\section{RESULTS}

Serial potassium estimations were carried out on eight consecutive patients undergoing open cardiac surgery under profound hypothermia, the length of circulatory arrest varying from 33 to 65 minutes. The concentrations were calculated for each $2 \cdot 5^{\circ} \mathrm{C}$. change in temperature, the temperature used being the mean of the oesophageal and nasopharyngeal temperatures. This mean was found to correspond closely with the temperature of the blood in the venous outflow from the right atrium. The oesophageal temperature measured the temperature of the blood flowing through the heart and the nasopharyngeal recorded approximately the temperature of the blood flowing through the brain. The results of the eight cases, together with the mean serum potassium levels shown superimposed with the strong black line, are given in Figure 1. The variations from the mean are shown in Table I. The samples taken from the reservoirs and heat exchanger were all found to correspond, within the limits of experimental error, to the last specimen taken from the venous outflow before circulatory arrest.

Urine samples were collected in six out of the eight cases. Of the other two patients, one produced no urine during the whole of anaesthesia and in the other the catheter had either slipped or become blocked early on as the bladder was found to contain urine at the end of the operation. A summary of the six cases is given in Table II.

The serum potassium level tended to rise as the temperature fell and the rate of increase was more

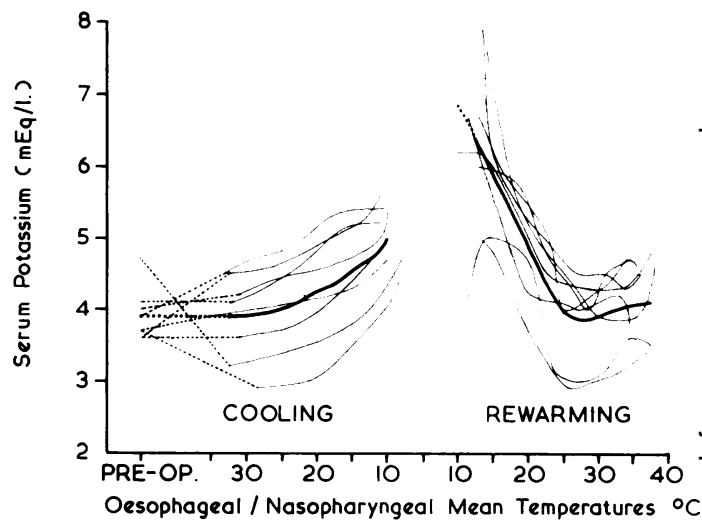

FIG. 1. Results of serum potassium estimations related tis temperature in eight cases.

TABLE II

URINARY POTASSIUM EXCRETION (mEq./min.) AT VARIOUS STAGES OF PROFOUND HYPOTHERMIA

\begin{tabular}{clll} 
Case No. & Cooling & Circulatory Arrest & Rewarming \\
\hline 1 & 0.005 & No urine & 0.07 \\
2 & Approx. 0.1 & No urine & $\left\{\begin{array}{l}0.08 \text { up to } 25 \\
0.0225^{\circ} \mathrm{C} .37^{\circ} \\
\text { No urine }\end{array}\right.$ \\
3 & No urine & No urine & No urine \\
5 & 0.1 & No urine & No urine \\
6 & 0.04 & No urine & No urine
\end{tabular}

rapid at lower temperatures. At the end of circulatory arrest the level was considerably higher than at the beginning. This is in agreement with the work of Wright (1962) who found that in dogs there was mean rise of $1.5 \mathrm{mEq}$./litre during arrest; in contrasio to our results he observed a slight fall during cooling

On rewarming, the potassium level showed a fal $\mathbb{B}$ from a mean of $6.5 \mathrm{mEq}$./litre at $10^{\circ} \mathrm{C}$. to $3.85^{3}$ mEq./litre at $27 \cdot 5^{\circ} \mathrm{C}$., regardless of the time at whiche this occurred, and thereafter remained almost constant as the temperature continued to rise.

Urinary potassium does not account for the whole of the fall in the serum potassium level? During rewarming in case $2,1 \cdot 2 \mathrm{mEq}$. of potassium 5 was excreted in 15 minutes while the serum potassium

TA B LE I

OESOPHAGEAL AND NASOPHARYNGEAL MEAN TEMPERATURES AND VARIATIONS IN SERUM POTASSIUM LEVELS IN PROFOUND HYPOTHERMIA

\begin{tabular}{|c|c|c|c|c|c|c|}
\hline \multirow[b]{3}{*}{ Cooling } & \multicolumn{6}{|c|}{ Temperature $\left({ }^{\circ} \mathrm{C}.\right)$} \\
\hline & $\begin{array}{l}\text { Pre- } \\
\text { operatively }\end{array}$ & 30 & 25 & 20 & 15 & 10 \\
\hline & & & & & & \\
\hline $\begin{array}{l}\text { Variation } \\
\text { Mean }\end{array}$ & $\begin{array}{c}3 \cdot 6 \cdot 4 \cdot 7 \\
3 \cdot 9\end{array}$ & $\begin{array}{c}3 \cdot 0-4 \cdot 65 \\
3 \cdot 9\end{array}$ & $\begin{array}{c}2 \cdot 8-4 \cdot 85 \\
4 \cdot 0\end{array}$ & $\begin{array}{c}3 \cdot 0-5 \cdot 2 \\
4 \cdot 25\end{array}$ & $\begin{array}{c}3 \cdot 5-5 \cdot 4 \\
4 \cdot 55\end{array}$ & $\begin{array}{c}4 \cdot 05-5 \cdot 7 \\
5 \cdot 0\end{array}$ \\
\hline
\end{tabular}

\begin{tabular}{|c|c|c|c|c|c|c|}
\hline & \multicolumn{6}{|c|}{ Temperature $\left({ }^{\circ} \mathrm{C}.\right)$} \\
\hline & 10 & 15 & 20 & 25 & 30 & 35 \\
\hline \multicolumn{7}{|c|}{ Rewarming } \\
\hline $\begin{array}{l}\text { Variation } \\
\text { Mean }\end{array}$ & $\begin{array}{r}5 \cdot 2-7 \cdot 9 \\
6 \cdot 75\end{array}$ & $\begin{array}{c}4 \cdot 8-7 \cdot 0 \\
5 \cdot 9\end{array}$ & $\begin{array}{c}3 \cdot 7-5 \cdot 5 \\
4 \cdot 9\end{array}$ & $\begin{array}{c}2 \cdot 95-4 \cdot 65 \\
4 \cdot 0\end{array}$ & $\begin{array}{c}3 \cdot 0-4 \cdot 5 \\
3.9\end{array}$ & $\begin{array}{c}3.25 .4 .75 \\
4.05\end{array}$ \\
\hline
\end{tabular}


level fell from 5.2 to $2.9 \mathrm{mEq}$./litre, a total loss from the serum of approximately $9 \mathrm{mEq}$.

\section{DISCUSSION}

Most workers have studied the potassium changes during hypothermia in dogs and a review of the literature has produced only two references to estimations carried out in man (Munday et al., 1958; Swan, Zeavin, Holmes, and Montgomery, 1953) during which the temperatures were only lowered to $30^{\circ} \mathrm{C}$. Previous workers did not show the potassium changes observed by us but this is presumably due to insufficiently low levels of hypothermia.

We found that lowering the temperature to $20^{\circ} \mathrm{C}$. did not produce constant changes in the serum potassium levels. In two patients the potassium level fell by $0.9 \mathrm{mEq}$./litre and $2.0 \mathrm{mEq}$./litre respectively. Yonce et al. (1962), working with dogs, observed a fall of 1.3 mEq./litre. Swan et al. (1953), Munday et al. (1958), and Wright (1962) obtained similar results. In contrast Sarajas (1962) observed a rise in serum potassium levels similar to that occurring in two of our patients in whom the potassium increased by 1.25 and $1.3 \mathrm{mEq}$./litre respectively. In the other four patients there was a slight rise.

On lowering the temperature from $20^{\circ} \mathrm{C}$. to $10^{\circ} \mathrm{C}$. we observed a significant rise in six out of the eight patients. In the other two a rise occurred but this was not so pronounced.

It is difficult to assess the possible causes for the changes that we found. Pizzoferrato and Lami (1961) suggest that surgical trauma does not clearly influence variations in the potassium level. Metabolic acidosis and hypoventilation cause a rise in the serum potassium (Evans, 1950; Marks, 1950; Sarajas, 1962) whereas hyperventilation tends to depress it (Swan et al., 1953). Our patients tended to be hyperventilated during cooling and rewarming but the $p \mathrm{H}$ was found to fall during circulatory arrest when ventilation was discontinued. The acidosis that occurred was probably partly responsible for the rise in serum potassium levels during the period of circulatory arrest.

Some anaesthetic agents produce changes in the serum potassium level. Fluothane, which is known to cause a rise (Staib, Bernard, Kirchner, Maurath, and Müller, 1961), was used for the induction of anaesthesia but once the temperature had been lowered to $30^{\circ} \mathrm{C}$. the patients were ventilated with
$100 \%$ oxygen only. It seems unlikely, therefore, that changes in the potassium level occurring below this temperature were due to Fluothane.

Kenyon (1961) suggests that there is a temporary depression in the function of the cell membrane during the period of arrest with a corresponding inhibition of the potassium pump mechanism. Further observations on this matter have been made by Freeman-Narrod and Goodford (1962) who showed that when slices of guinea-pig taenia coli are equilibrated in Kreb's solution at $4^{\circ} \mathrm{C}$. and $20^{\circ} \mathrm{C}$. respectively for one hour there was an intracellular loss of potassium of up to $75 \%$ at $4^{\circ} \mathrm{C}$. and only $50 \%$ at $20^{\circ} \mathrm{C}$. In the former the loss was recovered in 15 minutes when the equilibrated slices were immersed at $37^{\circ} \mathrm{C}$., whereas the tissue slices equilibrated at $20^{\circ} \mathrm{C}$., when rewarmed to $37^{\circ} \mathrm{C}$., regained potassium at a much slower rate.

The rise in serum potassium levels during circulatory arrest at about $10^{\circ} \mathrm{C}$. and the fall during the first half of rewarming, with a mean low level at $27 \cdot 5^{\circ} \mathrm{C}$., were a constant feature of our experiments. During cooling and rewarming the changes that occur below $20^{\circ} \mathrm{C}$. are more significant than those occurring above that temperature. On the evidence of the six cases in which the urinary potassium excretion was estimated, these changes in the serum potassium are not explained by the loss of potassium in the urine.

We are indebted to Dr. H. Lehmann and Dr. T. B. Boulton for their encouragement and advice, and to Professor M. de B. Daly for his critical comments. We also wish to thank Mr. O. S. Tubbs and Mr. I. M. Hill for permission to study their patients.

\section{REFERENCES}

Drew, C. E., and Anderson, I. M. (1959). Lancet, 1, 748.

Dunlop, M., and Curnow, D. H. (1962). Med. J. Aust., 1, 803.

Evans, E. I. (1950). Ann. Surg., 131, 945.

Freeman-Narrod, M., and Goodford, P. J. (1962). J. Physiol. (Lond.), 163, 399.

Gollan, F., Rudolph, G. G., and Olsen, N. S. (1957). Amer. J. Physiol., 189, 277

Hurt, R. L. (1962). Lancet, 1, 783.

Kenyon, J. R. (1961). Brit. med. Bull., 17, 43.

Marks, L. J. (1950). Ann. Surg., 132, 20.

Munday, K. A., Blane, G. F., Chin, E. F., and Machell, E. S. (1958). Thorax, 13, 334.

Pizzoferrato, A., and Lami, L. (1961). Chir. Organi Mov., 50, 410.

Sarajas, H. S. S. (1962). Ann. Chir. Gynaec. Fenn., 51, 253.

Swan, H., Zeavin, I., Holmes, J. H., and Montgomery, V. (1953). Ann. Surg., 138, 360.

Staib, I., Bernard, M., Kirchner, E., Maurath. J., and Müller, K. H. (1961). Anaesthesist, 10, 330.

Wright, M. P. (1962). Bull. Soc. int. Chir., 21, 625.

Yonce, L. R., Dykers, J. R. Jr., and McGee, J. W. (1962). Amer. J. Physiol., 202, 277. 